\author{
K. A. Siebenrock - T. Gerich - R. P. Jakob
}

\title{
Sequential intramedullary nailing of open tibial shaft fractures after external fixation
}

Received: 9 October 1995

\begin{abstract}
We reviewed 32 tibial shaft fractures in 31 patients treated with sequential intramedullary nailing after primary external fixation. There were 30 open fractures and 2 closed injuries with severe blunt trauma requiring fasciotomy. Fifty per cent of the fractures were classified as Gustilo type III A and B injuries [13]. The mean external fixation treatment averaged 6.6 weeks, and secondary intramedullary nailing was done on average 7.4 weeks after injury. In $50 \%$ of the fractures, secondary nailing was done at the same procedure as removal of the external fixation. Overall, the incidence of osteomyelitis and nonunion was $3.1 \%$ each and of malunion $19 \%$. The time to full weight-bearing averaged 31.2 weeks. The results were separately analyzed according to Gustilo types and subtypes. In the Gustilo type III B injuries, the incidence of osteomyelitis and non-union was $11 \%$, while malunion occurred in $33 \%$. The time to full weight-bearing averaged 53 weeks. These results support the conclusion that this treatment modality is a valid alternative to other treatment options. However, previous pintract infections should be regarded as a contraindication for secondary nailing.
\end{abstract}

\section{Introduction}

The debate on how to treat high-energy and open tibial shaft fractures has intensified with the introduction of unreamed interlocking intramedullary devices $[26,32,35]$. Controversy still exists about the optimal treatment method

Beispiel: Presented at the 15th Annual Meeting on Mycorrhizae, Chicago, 1992

K. A. Siebenrock $(\bowtie) \cdot$ R. P. Jakob

Department of Orthopaedic Surgery, Inselspital,

University of Bern, CH-3010 Bern, Switzerland

T. Gerich

Unfallchirurgische Klinik der Medizinischen Hochschule, Hannover, Germany for severe open Gustilo type III fractures [13]. Recently, some authors have favoured primary unreamed interlocking nailing in these fracture types $[26,35]$. Common problems seen with external fixation in the management of Gustilo type III fractures include pintract, soft-tissue and bone infections, as well as high non-union and malunion rates $[9,10,18]$. In an attempt to lower the complication rates associated with external fixation treatment in these injuries, several investigators have suggested sequential intramedullary nailing after complete soft-tissue healing $[4,23,24]$. In our department this method of treatment has increasingly been applied as a planned procedure in recent years. This study reports the results of 32 fractures treated with sequential nailing of open tibial shaft fractures after primary treatment with an external fixation device over a time period of 6 years.

\section{Materials and methods}

A retrospective analysis of 31 consecutive patients with 32 tibial shaft fractures (initial injury occurred between 1986 and 1992) was done (Table 1). All patients were primarily treated at our department with an external fixation device and subsequent conversion to an intramedullary nail after soft-tissue healing. The charts and the preoperative $X$-rays as well as the radiographs from the last follow-up control of all 32 cases were retrospectively reviewed. Follow-up information could be obtained in all cases at an average of 22.6 months (range 6-54 months) after injury. The mean age of the patients was 33 years (16-75 years) with a male to female ratio of $4: 1$. Seventy-one per cent of the patients had multiple injuries. According to the AO classification [25] there were $28 \%$ type A, $20 \%$ type B and $52 \%$ type C (comminuted) fractures. Two high-energy closed fractures required fasciotomy within $24 \mathrm{~h}$. In addition, two fasciotomies were done for two grade II open fractures within $36 \mathrm{~h}$ after injury. The 30 open fractures were classified according to Gustilo et al. [13]: 4 were type I, 10 as type II, 7 as type III A and 9 as type III B. There were no type III C injuries. All patients were treated within $24 \mathrm{~h}$ after injury with soft-tissue debridement and application of external fixation. In all but two cases a unilateral device (AO/ASIF tube external fixator) was used with two 5-mm Schanz screws both proximal and distal to the fracture site and two longitudinal bars. In the remaining two cases on $\mathrm{AO} / \mathrm{ASIF}$ external point clamp fixator was used, also with two clamps each on either side of the fracture. Conversion to an intramedullary nail was not done as a standard procedure at our de- 
Table 1 Average treatment data for open tibial shaft fractures classified according to Gustilo et al. [13]

a Type I group includes 2 patients with closed fractures

b Time of intramedullary nailing after injury

${ }^{c}$ interval $=$ time between removal of external fixation and intramedullary nailing. Softtissue procedures included debridement, secondary wound closure, skin grafts and muscle flaps

Table 2 Treatment results for open tibial shaft fractures classified according to Gustilo et al. [13]

a Type I group includes 2 patients with closed fractures

b Malunion is defined as angulation $>5^{\circ}$ in frontal plane and $>10^{\circ}$ in sagittal plane, $>10^{\circ}$ of rotation and $>1 \mathrm{~cm}$ of leg discrepancy

${ }^{c}$ Reduced joint mobility is defined as loss of motion in ankle joint $>10^{\circ}$ and knee joint $>$ $20^{\circ}$

\begin{tabular}{|c|c|c|c|c|c|c|}
\hline & \multirow{2}{*}{$\begin{array}{l}\text { External } \\
\text { fixation } \\
\text { treatment } \\
\text { (median } \\
\text { days) }\end{array}$} & \multirow{2}{*}{$\begin{array}{l}\text { Time of } \\
\text { intramedul- } \\
\text { lary nailing } \\
\text { (median } \\
\text { days) }^{\mathrm{b}}\end{array}$} & \multirow{2}{*}{$\begin{array}{l}\text { No interval } \\
\text { left }\end{array}$} & \multicolumn{2}{|l|}{ Interval } & \multirow{2}{*}{$\begin{array}{l}\text { Soft-tissue } \\
\text { procedures } \\
\text { per patient } \\
(n)\end{array}$} \\
\hline & & & & $<1$ week & $\begin{array}{l}1-3(4) \\
\text { weeks }\end{array}$ & \\
\hline $\begin{array}{l}\text { Type } \mathbf{I}^{\mathbf{a}} \\
(n=6)\end{array}$ & $\begin{array}{l}32 \\
(12-75)\end{array}$ & $\begin{array}{l}39 \\
(14-77)\end{array}$ & $2(33 \%)$ & $4(66 \%)$ & $0(0 \%)$ & 1.8 \\
\hline $\begin{array}{l}\text { Type II } \\
(n=10)\end{array}$ & $\begin{array}{l}29 \\
(5-150)\end{array}$ & $\begin{array}{l}38 \\
(5-150)\end{array}$ & $6(60 \%)$ & $3(30 \%)$ & $1(10 \%)$ & 2 \\
\hline $\begin{array}{l}\text { Type III A } \\
(n=7)\end{array}$ & $\begin{array}{l}28 \\
(7-105)\end{array}$ & $\begin{array}{l}31 \\
(7-120)\end{array}$ & $4(57 \%)$ & $1(14 \%)$ & $2(29 \%)$ & 2.6 \\
\hline \multirow[t]{3}{*}{$\begin{array}{l}\text { Type III B } \\
(n=9)\end{array}$} & $\begin{array}{l}49 \\
(16-94)\end{array}$ & $\begin{array}{l}56 \\
(16-108)\end{array}$ & $4(44 \%)$ & $2(22 \%)$ & $3(33 \%)$ & 3.2 \\
\hline & \multirow{2}{*}{$\begin{array}{l}\text { Time to full } \\
\text { weight- } \\
\text { bearing } \\
\text { (median } \\
\text { weeks) }\end{array}$} & \multirow[t]{2}{*}{ Malunion $^{\mathrm{b}}$} & \multirow[t]{2}{*}{ Non-union } & \multicolumn{2}{|l|}{ Infection } & \multirow{2}{*}{$\begin{array}{l}\text { Reduced } \\
\text { joint } \\
\text { mobility }\end{array}$} \\
\hline & & & & soft tissue & $\begin{array}{l}\text { osteo- } \\
\text { myelitis }\end{array}$ & \\
\hline $\begin{array}{l}\text { Type } \mathrm{I}^{\mathrm{a}} \\
(n=6)\end{array}$ & $\begin{array}{l}15 \\
(9-40)\end{array}$ & $0(0 \%)$ & $0(0 \%)$ & $0(0 \%)$ & $0(0 \%)$ & $0(0 \%)$ \\
\hline $\begin{array}{l}\text { Type II } \\
(n=10)\end{array}$ & $\begin{array}{l}27 \\
(18-42)\end{array}$ & $2(20 \%)$ & $0(0 \%)$ & $0(0 \%)$ & $0(0 \%)$ & $2(20 \%)$ \\
\hline $\begin{array}{l}\text { Type III A } \\
(n=7)\end{array}$ & $\begin{array}{l}27 \\
(10-33)\end{array}$ & $1(14 \%)$ & $0(0 \%)$ & $1(14 \%)$ & $0(0 \%)$ & $3(43 \%)$ \\
\hline $\begin{array}{l}\text { Type III B } \\
(n=9)\end{array}$ & $\begin{array}{l}41 \\
(18-128)\end{array}$ & $3(33 \%)$ & $1(11 \%)$ & $0(0 \%)$ & $1(11 \%)$ & $3(33 \%)$ \\
\hline
\end{tabular}

partment, but it has been performed more frequently in recent years, according to the surgeon's preference. Reasons for change included primary planning after soft-tissue healing in 19 fractures, bone healing problems in 10 fractures, loosening of the external fixation device in 2, and loss of reduction during treatment with external fixation in 1 . The majority of the cases were fixed with sequential nails before the routine use of the new solid unreamed $\mathrm{AO}$ tibial nail. Thus, in 26 of 32 cases $(81 \%)$ a reamed AO universal tibial nail was inserted, an unreamed solid $\mathrm{AO}$ tibial nail in 5 $(16 \%)$ and Ender rods in 1 (3\%). In 7 of 9 fractures $(78 \%)$ with a grade III B open lesion, fixation with a reamed nail was performed. The nails were statically locked in 10 cases (31\%) with subsequent dynamization in 8 of them at an average period of 6.5 months (4-9 months) after insertion. In two other cases $(6 \%)$ the nail was dynamically locked. At the last follow-up 11 nails (34\%) had been removed at an average period of 22 months (11-44 months) after insertion. The treatment results were analysed for all 32 fractures together and separately reviewed according to the Gustilo types and subtypes.

\section{Results}

The mean external fixation treatment time averaged 6.6 weeks (1-20 weeks). Sequential nail fixation was performed at an average of 7.4 weeks (1-20 weeks) after injury. Pin tract infection was defined as any persistent drainage from a pin site requiring intervention (enlargement of incision, etc.) or positive bacterial cultures from the pin-site area $[5,23]$. It was seen in three cases $(9.4 \%)$. Laboratory results concerning infection parameters (erythrocyte sedimentation rate, ESR, white cell counts, WBC, C-reactive protein) within 2 weeks prior to sequential nail fixation were available in 10 cases. Of these results $60 \%$ was within normal limits, $20 \%$ mildly elevated (WBC between 10000 and $12000, \mathrm{ESR}<30$ ), and in $20 \%$ there was a moderate elevation of ESR ( 45 and 68 , respectively). All of these 10 cases underwent nailing with uneventful healing. Thus, no correlation could be drawn between elevation of these parameters and subsequent infection. In 16 fractures $(50 \%)$ nailing was done at the same procedure as external fixation removal. In 10 fractures there was an interval of 1 week between removal of the external fixation and secondary nailing. In 5 cases the interval spanned 1-3 weeks, and in 1 case the interval was 4 weeks. Time to full weight-bearing averaged 31.2 weeks (9-126 weeks). Malunion was defined as angulation in the frontal plane of more than $5 \mathrm{deg}$, angulation in the sagittal plane or rotation of more than $10 \mathrm{deg}$, as well as shortening of the leg by more than $1 \mathrm{~cm}$. Rotation and leg shortening were evaluated clinically. In cases with fractures of the contralateral leg or ipsilateral femur fractures, leg length measurement was obtained by comparing the length of the lower legs on radiographs taken from both sides. Routinely, X-ray of the uninvolved lower leg 
was done before secondary nail fixation to plan the correct length of the nail. The long bones of the contralateral leg were fractured in five and the ipsilateral femur in three cases. In three of these eight cases a conclusive evaluation of leg length discrepancy could not be done. According to the definitions above a malunion was observed in six fractures $(19 \%)$. Non-union occurred in one fracture $(3 \%)$ due to bone infection. Soft-tissue infection was seen in one patient who went on to uneventful bone healing. Osteomyelitis developed in the above-listed case (3\%) with subsequent non-union and breakage of a nail. In this case another nail was inserted after intramedullary reaming. However, union was not achieved until removal of the second nail and plating of the shaft with additional bone grafting. Further complications included hypaesthesia in the medial calf in two cases, extensor motor weakness due to traumatic peroneal nerve palsy in two, incomplete compartment syndrome in one, asymptomatic non-union of the fibula in one and chronic pain at the fracture site in two. Reduced joint mobility of the knee and/or ankle joint of more than $10 \mathrm{deg}$ was recorded in eight cases (25\%). Cases with concomitant injuries to the ligaments of the knee or ankle joint were not excluded and were counted as possibly secondary to the fracture of the lower leg. In the vast majority (seven cases) there was a reduced dorsal extension of the ankle joint. In two cases this was due to posttraumatic incomplete peroneal nerve palsy. In the remaining case there was a 20 deg loss of flexion of the knee joint (Table 2).

The results were separately analysed according to different Gustilo fracture (sub)types and are listed in Tables 1 and 2. The two patients with closed fractures were added to the patients with type I fractures. In all nine cases with Gustilo type III B fractures, a muscle flap for soft-tissue coverage was performed. Muscle flaps included five hemisoleus flaps, a combined hemisoleus and medial gastrocnemius flap in one case, and three free latissimus dorsi flaps. Definite soft-tissue coverage including muscle flaps was achieved at primary surgery in three $(33 \%)$ of the Gustilo type III B cases. In the remaining six fractures, coverage with a muscle flap was performed between the 2 nd and 17 th day after injury.

Bone grafting was done in 5 cases (56\%) with type III $B$ fractures at an average of 4 months ( 2 week-11 months) after injury. In the seven cases with type III A fractures, wound closure was obtained by skin grafting after an average of two soft-tissue debridements. In this latter group bone grafting was performed only in one case (14\%) 6 weeks after injury.

\section{Discussion}

The reported infection rates for treatment of open tibial shaft fractures with external fixation range from $7 \%$ to $30 \%$ depending on the severity of the fractures $[2,3,8$, $18,30,32]$. Malunion rates range from $10.5 \%$ to $46 \%$, and non-union is reported in $11 \%$ to $48 \%[1,2,18,30,32]$. Time to union in type III fractures with external fixation ranged from 30 to 38 weeks and averaged 47.2 weeks when only type III B injuries were included $[5,10,18]$. Infection rates ranged from $29 \%$ to $35 \%$ in type III B fractures $[8,10]$. A malunion rate of $71 \%$ was reported in this injury type treated with external fixation alone by CourtBrown et al. [10].

Infection rates for primary reamed nailing of acute tibial shaft fractures in the literature range from $6 \%$ to $20 \%$ $[6,15,17,19,28]$. As this procedure is not recommended in severe open fractures $[7,9,14]$, most patients included in these studies had type I and type II open fractures. To our knowledge only Court-Brown et al. [11, 12] have published results of primary reamed nailing in type III B open tibial shaft fractures. They found infection rates of $9.5 \%$ in type III injuries. In type III B fractures they reported infection rates of $12.5 \%$ and $23 \%$. In the latter patient groups time to union averaged 50.1 and 71 weeks, and mal-union was found in $15 \%$.

In patient groups with various types of open tibial fractures, infection rates after primary unreamed nailing with flexible and solid devices were found to be within 3.3\%$8 \%[16,21,22,33-35]$. Malunion with flexible devices was recorded in $17 \%$ to $21 \%$ and non-union with both flexible and solid nails in $2.4 \%-6.3 \%[18,36]$. Infection rates ranged from $6 \%$ to $17 \%$ for type III fractures and were reported in $25 \%$ after the same treatment in type III $\mathrm{B}$ fractures [18, 32, 34-36]. In type III fractures nonunion rates ranged from $5.8 \%$ to $26 \%[18,35,36]$, malunion was reported in $26 \%$ [32] with solid devices, and the average time for healing is reported to be 6.8 months. In their prelimary report about treating 19 open tibial shaft fractures (47\% type III) with solid interlocking nails, Piccioni and Guanche [26] found no infection at all. However, at the time of the report, 5 fractures had not definitely healed and $3(16 \%)$ had already undergone secondary nailing for delayed bone healing. Krettek et al. [20] could not find infection in 10 patients with type III B fractures primarily treated with an unreamed solid nail. However, the study is limited by low patient numbers. Additionally, they reported muscle flap coverage in only $10 \%$ of their cases, whereas in the present study in all of the patients with type III B injuries, a muscle flap was performed. This may indicate classification problems as well.

A number of authors advocate against secondary nailing of open fractures after primary treatment with external fixation $[5,7,14,24]$. Infection rates were reported to range from $25 \%$ to $44 \%$ with this treatment regimen in two studies [23, 24]. However, in both of these studies there was pin tract infection during external fixation treatment in five of six and in five of seven patients who consequently developed deep infection after sequential nailing. In $80 \%$ of the patients with pin tract infection and further osteomyelitis, the same bacteria were isolated before and after changing to a nail. Maurer et al. [23] demonstrated the significant increase in risk (to $71 \%$ ) of developing subsequent deep infection when nailing was done after evidence of pin tract infection. Consequently, they listed pin tract infection as a contraindication for sec- 
Table 3 Interval length between removal of extemal fixation and sequential nailing and number of cases with consequent infections

\begin{tabular}{|c|c|c|c|c|c|}
\hline Reference & $\begin{array}{l}\text { Number of } \\
\text { patients }\end{array}$ & $\begin{array}{l}\text { Number of } \\
\text { infections }\end{array}$ & $\begin{array}{l}\text { Interval length } \\
\text { in study }\end{array}$ & $\begin{array}{l}\text { Interval in cases } \\
\text { with infections }\end{array}$ & $\begin{array}{l}\text { Conclusions regarding } \\
\text { interval length and } \\
\text { incidence of infection }\end{array}$ \\
\hline Ahlers et al. [1] & 13 & 0 & 2 weeks (cast) & - & Recommended as done \\
\hline Blachut et al. [4] & 39 & 2 & $0-3$ weeks & $\begin{array}{l}1 \times 5 \text { days } \\
1 \times \text { no interval }\end{array}$ & No correlation to interval \\
\hline Bone and Johnson [6] & 5 & 0 & $7-10$ days & - & Recommended as done \\
\hline Maurer et al. [23] & 24 & 7 & 3 days -54 weeks & 9 days -14 weeks & $\begin{array}{l}>3 \text { weeks (based on study } \\
\text { in canine model) }\end{array}$ \\
\hline McGraw and Lim [24] & 16 & 7 & mean 3 weeks & $\begin{array}{l}1 \times \text { no interval } \\
6 \times \text { interval }^{b}\end{array}$ & $\begin{array}{l}\text { No correlation to interval } \\
\text { length found }\end{array}$ \\
\hline Puno et al. $[27]^{a, b}$ & & 1 & $5-7$ days & & Recommended as done \\
\hline Siebenrock et al. [31] & 24 & 1 & $0-4$ weeks & $1 \times 2$ weeks & $\begin{array}{l}\text { No correlation to } \\
\text { interval found }\end{array}$ \\
\hline
\end{tabular}

a Total number of patients not listed

${ }^{b}$ Detailed interval length not listed

ondary nailing. We strongly support this. The only patient who developed ostesmyelitis after sequential nailing in this study had clinical signs of former pin tract infection, although no pathological bacteria could be isolated from the pin tract site. In studies with a low incidence of pin tract infections, sequential nailing resulted in subsequent deep infections in only $4 \%-6 \%[4,31]$. Also, those studies comprised patient groups with different types of soft-tissue injuries. However, none of the 12 patients with type III fractures reported by Blachut et al. [4] developed infection after sequential nailing. In the present study the results were separately analysed for the different types of open injuries. The non-union and infection rates of $6 \%$ in type III fractures (11\% in type III B) and the malunion rates of $25 \%$ (33\% in type III B) indicate favorable results with the sequential treatment method, especially when compared with the treatment of type III injuries by external fixation alone $[5,8,10]$. Furthermore, two of the three malunion cases of the type III B fractures consisted only in leg shortening $(1-3 \mathrm{~cm})$. This is partially due to bone loss and comminuted fracture type. Primary nailing of type III injuries may be an alternative option. However, there are few studies that document the final outcome of severe, open, type III A and type III B injuries. Also, the limited stability with unreamed devices and the commonly found comminuted fracture pattern in these injuries may render primary unreamed nailing a less than optimal treatment option [7, 11, 14, 26, 34]. External fixation still has the advantage of a rigid fixation which can easily be achieved, especially in patients with multiple injuries.

When performing a sequential intramedullary nailing after external fixation, early exchange as soon as the soft tissues have healed safely seems to decrease the infection rates. Pin tract and deep infections are definitely lower when nailing was performed 2-6 weeks after the injury [4, $31]$ than $12-16$ weeks after injury $[23,24]$. Rommens et al. [29] demonstrated that a shorter treatment period with external fixation reduces the risk of pin tract colonization. The soft-tissue management itself plays another decisive role in the final outcome. A variety of studies show es- sential advantages of repeated aggressive soft-tissue management aiming at early definite skin cover and prophylactic bone grafting in severely comminuted fractures $[5$, $8,34]$. Muscle flaps and definite skin cover at primary surgery were performed in $33 \%$ of the patients with type III B injuries in this study. In $56 \%$ of the patients with type III B injuries, bone grafting was performed in the further course.

There is still debate about leaving an interval between removal of external fixation and sequential nail implantation. However, even in the studies with high infection rates, no significant benefit of an interval could be proven $[23,24]$. A number of authors have recommended different interval lengths, as shown in Table 3. In other studies no increased risk could be found when there was no interval at all, and nailing was done in the same procedure as the removal of external fixation $[4,31]$. In this study there was no interval for $50 \%$ of the patients. The only infection seen was in a patient in whom nailing was done 6 weeks after injury without leaving an interval. However, 2 weeks before this procedure there were clinical signs of pin tract infection, although cultures were negative. Reviewing the literature, we believe that this indicates a high risk of infection subsequent to a pin tract infection rather than the need to leave an interval. A previous pin tract infection should be strictly regarded as a contraindication for sequential nailing [24]. Definition of pin tract infection has been proposed as any drainage from pin tract sites (a) with positive cultures from pin site or (b) which requires any kind of intervention [5, 23].

In conclusions, sequential nailing after external fixation treatment is an effective treatment method for severe tibial shaft fractures including Gustilo type III A and B injuries. Based on our data as well as on a literature review, there is no significantly higher risk of infection when sequential intramedullary nailing is performed at the same procedure with external fixation removal given the strict criterion of absence of former pin tract infection. Aggressive soft-tissue management aiming at early wound coverage (including muscle flaps) and bone grafting plays an- 
other decisive role in the treatment of severe open tibial shaft fractures.

\section{References}

1. Ahlers J, Ritter G, Weigand H (1983) Die Marknagelung als Sekundäreingriff nach vorausgegangener Anwendung des Fixateur externe. Unfallchirurgie 9:83-91

2. Bach AW, Hansen ST (1989) Plates versus external fixation in severe open tibial shaft fractures. Clin Orthop $241: 89-94$

3. Behrens F, Searls K (1986) External fixation of the tibia. Basic concepts and prospective evaluation. J Bone Joint Surg [Br] 68: 246-254

4. Blachut A, Meek RN, O'Brien PJ (1990) External fixation and delayed intramedullary nailing of open fractures of the tibial shaft. J Bone Joint Surg [Am] 72:729-735

5. Blick SS, Brumback RJ, Lakatos R, Poka A, Burgess AR (1989) Early prophylactic bone grafting of high-energy tibial fractures. Clin Orthop 240:21-41

6. Bone LB, Johnson KD (1986) Treatment of tibial fractures by reaming and intramedullary nailing. J Bone Joint Surg [Am] 68: $877-887$

7. Brumback RJ (1992) Open tibial fractures. Current orthopaedic management. Instructional Course Lectures, Vol XLI, pp 101117

8. Caudle RJ, Stern PJ (1987) Severe open fractures of the tibia. J Bone Joint Surg [Am] 69:801-807

9. Chapman MW (1986) The role of intramedullary fixation in open fractures. Clin Orthop 212:26-34

10. Court-Brown CM, Wheelwright EF, Christie J, McQueen MM (1990) External fixation for type III open fractures. J Bone Joint Surg [Br] 72:801-804

11. Court-Brown CM, McQueen MM, Quba AA, Christie J (1991) Locked intramedullary nailing of open tibial fractures. J Bone Joint Surg [Br] 73:959-964

12. Court-Brown CM, Keating JF, McQueen MM (1992) Infection after intramedullary nailing of the tibia. J Bone Joint Surg [Br] $74: 770-774$

13. Gustilo RB, Mendoza RM, Williams DN (1984) Problems in the management of type III (severe) open fractures: a new classification of type III open fractures. J Trauma 24:742-746

14. Gustilo RB, Merkow RL, Templeman D (1990) Current concepts review - the management of open fractures. J Bone Joint Surg [Am] 72:299-304

15. Hamza KN, Dunkerley GE, Murray CMM (1977) Fractures of the tibia. A report on fifty patients treated by intramedullary nailing. J Bone Joint Surg [Br] 53:696-700

16. Harvey FG, Hodgkinson ATH, Harvey PM (1975) Intramedullary nailing in the treatment of open fractures of the tibia and fibula. J Bone Joint Surg [Am] 57:909-915

17. Henley B (1989) Intramedullary devices for tibial fracture stabilization. Clin Orthop 240:87-96

18. Holbrook JL, Swiontkowski MF, Sanders R (1989) Treatment of open fractures of the tibial shaft: Ender nailing versus external fixation. J Bone Joint Surg [Am] $71: 1231-1238$
19. Klemm KW, Börner M (1986) Interlocking nailing of complex fractures of the femur and tibia. Clin Orthop 212:89-100

20. Krettek C, Haas N, Schandelmaier P, Frigg R, Tscherne H (1991) Unreamed tibial nail in tibial shaft fractures with severe soft tissue damage. Initial clinical experiences. Unfallchirurg 94:579-587

21. Merle d'Aubigne R, Maurer P, Zucman J, Masse Y (1974) Blind intramedullary nailing for tibial fractures. Clin Orthop $105: 267-275$

22. Lottes JO (1974) Medullary nailing of the tibia with the triflange nail. Clin Orthop 105:253-266

23. Maurer DJ, Merkow RL, Gustilo RB (1989) Infection after intramedullary nailing of severe open tibial fractures initially treated with external fixation. J Bone Joint Surg [Am] 71:835838

24. McGraw JM, Lim EVA (1988) Treatment of open tibial shaft fractures. J Bone Joint Surg [Am] 70:900-911.

25. Müller ME, Allgöwer M, Schneider R, Willenegger H (1991) Manual of internal fixation. Techniques recommended by the AO/ASIF Group. Springer, Berlin Heidelberg New York

26. Piccioni L, Guanche CA (1992) Clinical experience with unreamed locked nails for open tibial fractures. Orthop Rev 21: 1213-1219

27. Puno RM, Teynor JT, Nagano J, Gustilo RB (1986) Critical analysis of results of treatment of 201 tibial shaft fractures. Clin Orthop 212: 113-121

28. Rommens PM, Coosemans W, Broos PLO (1989) The difficult healing of segmental fractures of the tibial shaft. Arch Orthop Trauma Surg 108:238-242

29. Rommens P, Gielen J, Broos P, Gruwez J (1989) Intrinsic problems with the external fixation device of Hoffmann-VidalAdrey: a critical evaluation of 117 patients with complex tibial shaft fractures. J Trauma 29:630-638

30. Rosso R, Martinoli s, Leutenegger A, Ruedi T (1989) Der dynamisierte Fixateur externe. Anwendung und Probleme. Helv Chir Acta 56:241

31. Siebenrock KA, Schillig B, Jakob RP (1993) Treatment of complex tibial shaft fractures. Arguments for early secondary intramedullary nailing. Clin Orthop $290: 269-274$

32. Swanson TV, Spiegel JD, Sutherland TB, Bray TJ, Chapman MW (1990) A prospective, comparative study of the Lottes nail versus external fixation in 100 open tibial fractures. Orthop Trans 14:716-717

33. Velazco A, Whitesides TE, Fleming LL (1983) Open fractures of the tibia treated with the Lottes nail. J Bone Joint Surg [Am] $65: 879-885$

34. Whittle AP, Russell TA, Taylor C, Lavelle DG (1990) Treatment of open tibial shaft fractures with non-reamed interlocking intramedullary nails. Orthop Trans 14:717

35. Whittle AP, Russell TA, Taylor C, Lavelle DG (1992) Treatment of open fractures of the tibial shaft with the use of interlocking nailing without reaming. J Bone Joint Surg [Am] 74 : 1162-1171

36. Wiss DA (1986) Flexible medullary nailing of acute tibial shaft fractures. Clin Orthop 212:122-132 